for

\title{
Carbon Dots Detect Water-to-Ice Phase Transition and Act as Alcohol Sensors via Fluorescence Turn-Off/On Mechanism
}

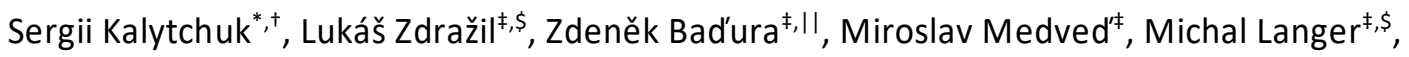 \\ Markéta Paloncýová ${ }^{\ddagger}$, Giorgio Zoppellaro ${ }^{\ddagger}$, Stephen V. Kershaw ${ }^{\perp}$, \\ Andrey L. Rogach ${ }^{\perp}$, Michal Otyepka ${ }^{\ddagger}$, and Radek Zbořil ${ }^{*},+, \S$
}

${ }^{\dagger}$ Regional Centre of Advanced Technologies and Materials, Czech Advanced Technology and Research Institute, Palacký University Olomouc, Šlechtitelů 27, Olomouc, 783 71, Czech Republic

${ }^{\ddagger}$ Regional Centre of Advanced Technologies and Materials, Faculty of Science, Palacký University Olomouc, Šlechtitelů 27, Olomouc, 783 71, Czech Republic

\$Department of Physical Chemistry, Faculty of Science, Palacký University Olomouc, 17. listopadu 12, Olomouc, 771 46, Czech Republic

"Department of Experimental Physics, Faculty of Science, Palacký University Olomouc, 17. listopadu 12, Olomouc, 786 41, Czech Republic

${ }^{\perp}$ Department of Materials Science and Engineering, and Center for Functional Photonics (CFP), City University of Hong Kong, 83 Tat Chee Avenue, Hong Kong S.A.R., China

${ }^{\S}$ Nanotechnology Centre, VŠB-Technical University of Ostrava, 17. listopadu 2172/15, Ostrava-Poruba, 708 00, Czech Republic

*Correspondence to: sergii.kalytchuk@upol.cz (S.K.), radek.zboril@upol.cz (R.Z.) 


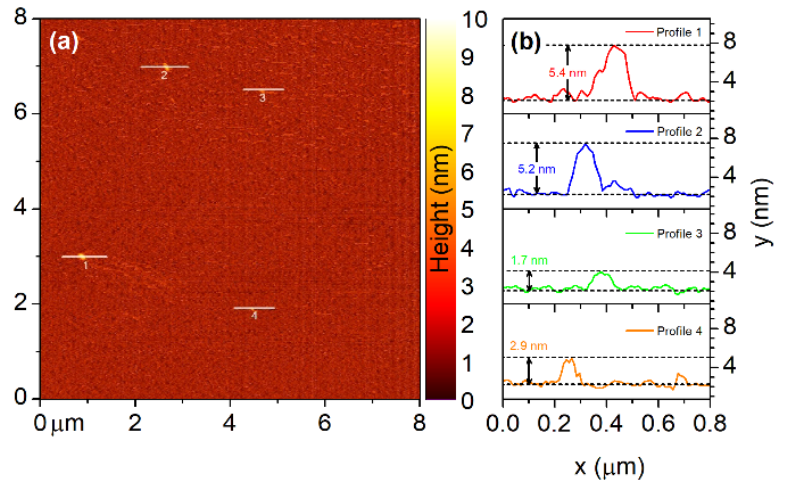

Figure S1. (a) Representative height-mode AFM topography image of CDs. (b) Line scan profiles of four individual CDs.

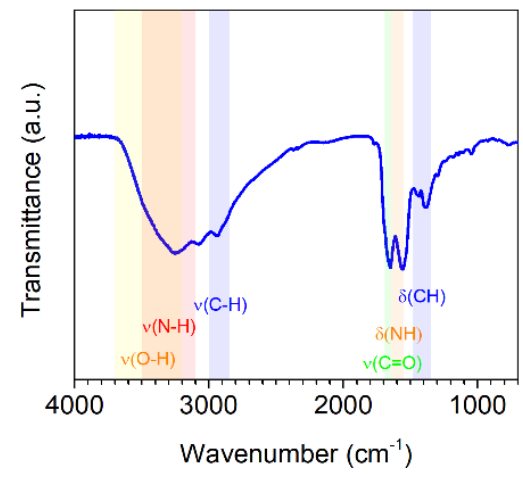

Figure S2. FTIR spectrum of CDs.
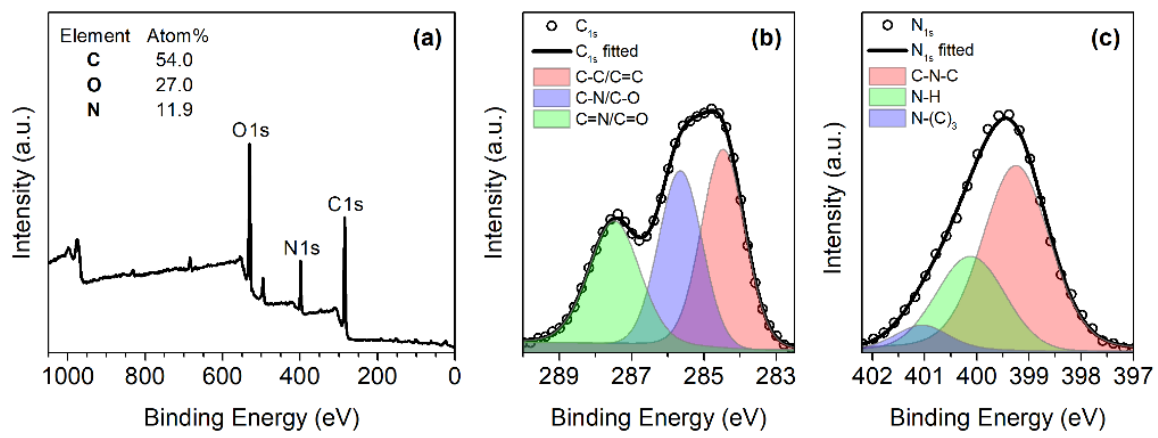

Figure S3. (a) XPS spectrum of CDs. Elemental composition is given as obtained from the XPS analysis. (b) High-resolution C 1s XPS spectrum. (c) High-resolution N 1s XPS spectrum. 


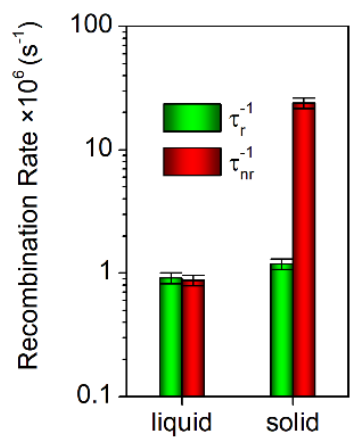

Figure S4. Radiative (green bars) and nonradiative (red bars) recombination rates for CDs dispersed in water in liquid and solid (frozen) states.
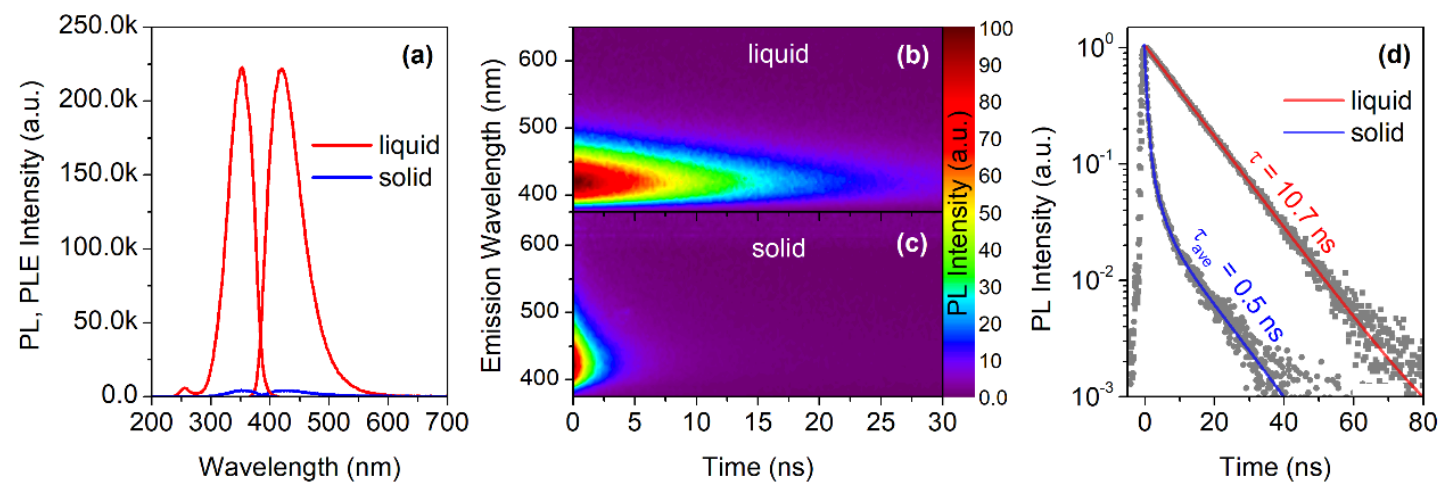

Figure S5. Influence of liquid-to-solid (water-to-ice) phase transition in the solvent (water) on steady-state and timeresolved PL of N,S-CDs synthesized using citric acid and L-cysteine with molecular fluorophores 5-oxo-3,5-dihydro- $2 \mathrm{H}$ thiazolo [3,2-a] pyridine-3,7-dicarboxylic acid (TPDCA) and 5-oxo-3,5-dihydro-2H-thiazolo [3,2-a] pyridine-7-carboxylic acid (TPCA). ${ }^{1}$ (a) Non-normalized PL and PLE intensity of N,S-CDs in liquid and solid state. $(b, c)$ Time-resolved PL emission color maps of N,S-CDs in liquid and solid state. (d) Corresponding PL decays for N,S-CDs collected at emission maximum in liquid and solid (ice) state.
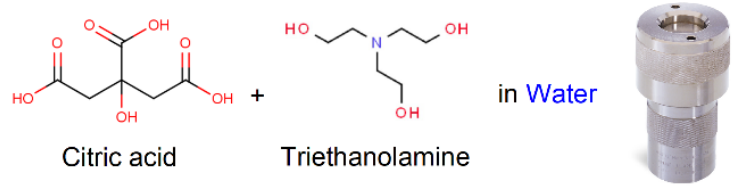

(a)
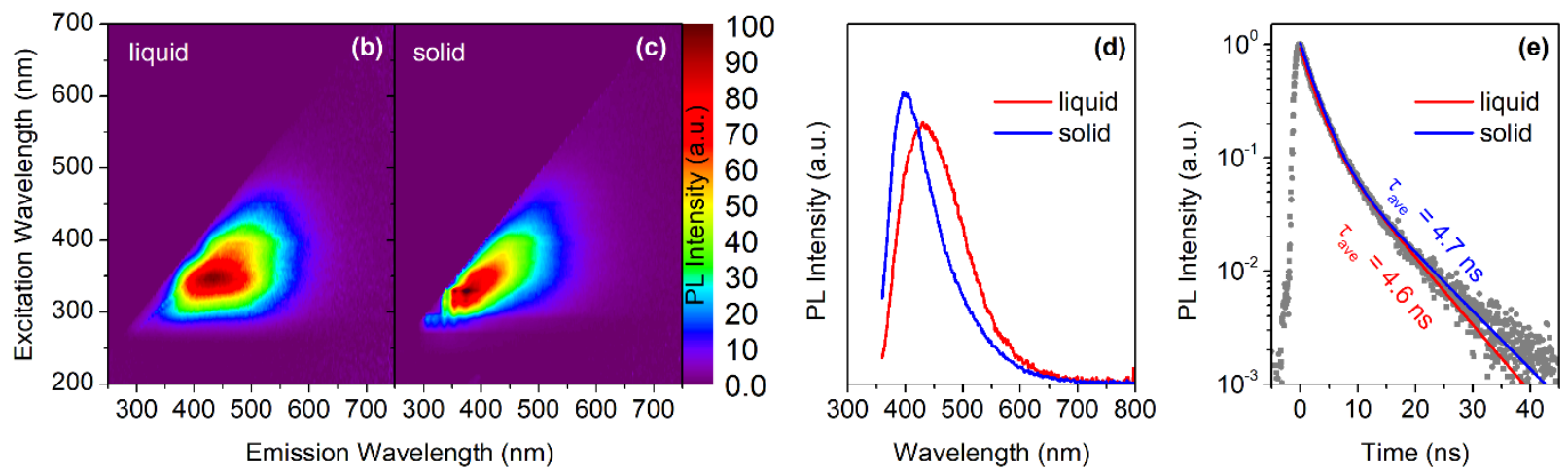

Figure S6. Synthesis and characterization of control CDs, without formation of the molecular fluorophore IPCA (CD control). (a) Schematics of the reaction scheme used for the preparation of $C D_{\text {control. }}$ (b) PL excitation-emission color map in liquid state, $T=2^{\circ} \mathrm{C}$. (c) PL excitation-emission color map in solid state $\left(T=-5^{\circ} \mathrm{C}\right)$. (d) Non-normalized PL emission in liquid and solid state $\left(\lambda_{\mathrm{ex}}=352 \mathrm{~nm}\right)$. (e) PL decays in liquid and solid (ice) state. 

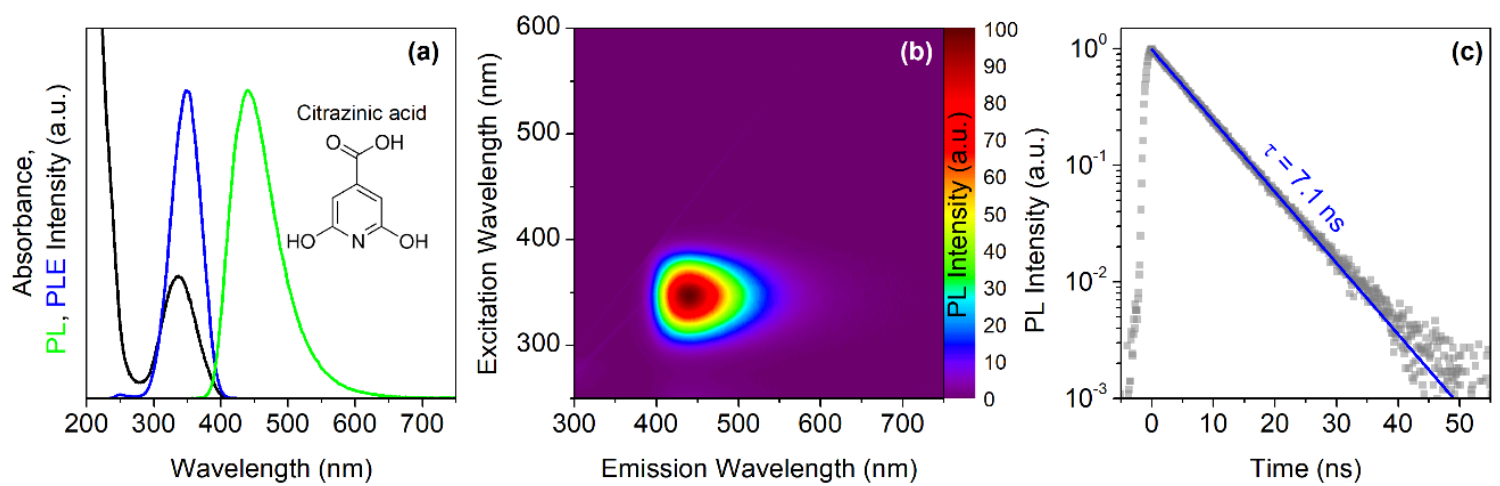

Figure S7. Optical characterization of citrazinic acid dispersed in water at room temperature. (a) Optical absorption (black curve), PL excitation (blue curve, $\lambda_{\mathrm{em}}=441 \mathrm{~nm}$ ) and PL emission (green curve, $\lambda_{\mathrm{ex}}=350 \mathrm{~nm}$ ) spectra. (b) PL excitationemission color map. (c) PL decay collected at the emission maximum.
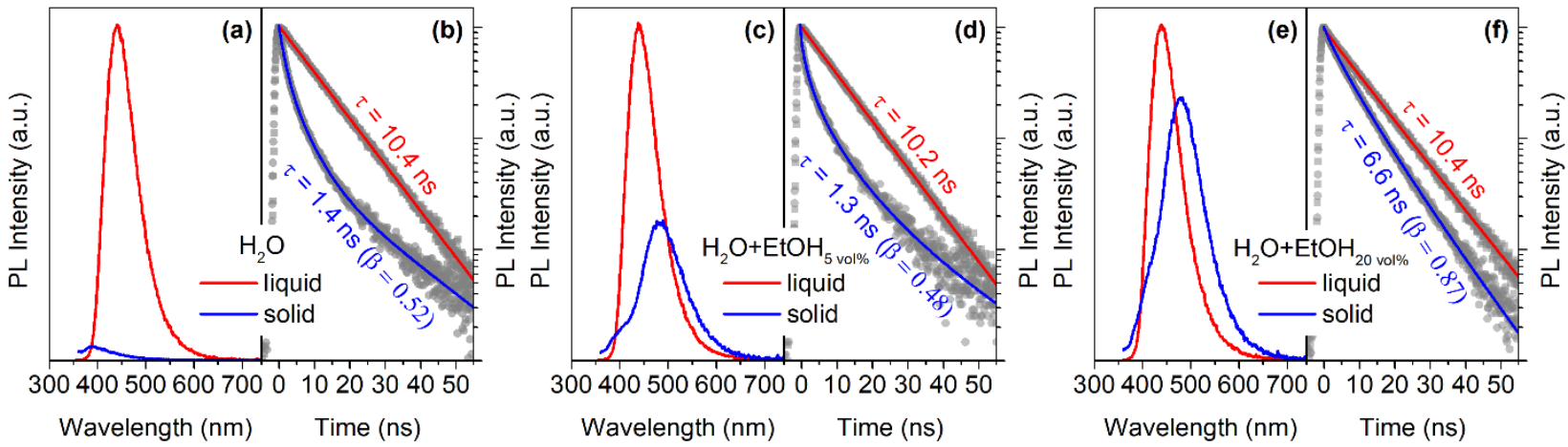

Figure S8. Influence of liquid-to-solid (water-to-ice) phase transition in the solvent (water or water-ethanol mixture with different concentration of ethanol) on steady-state and time-resolved PL of citrazinic acid. (a,c,e) Non-normalized PL intensity in liquid $\left(T=2^{\circ} \mathrm{C}\right.$ ) and solid (at temperature $5^{\circ} \mathrm{C}$ below the freezing point of corresponding solvent mixture) state. $(b, d, f)$ Corresponding PL decays collected at emission maximum in liquid and solid (ice) state.
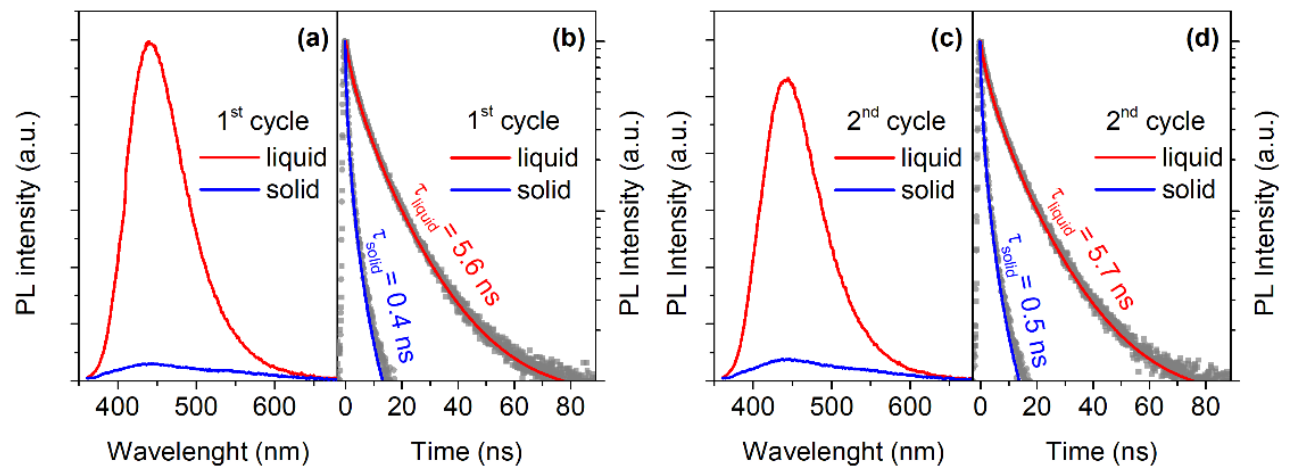

Figure S9. PL emission spectra $(a, c)$ and PL decays $(b, d)$ demonstrating reversibility over two sequential cycles of freezing and melting of $\mathrm{CDs}$ in aqueous colloidal solution. Liquid sample was measured at $T=2^{\circ} \mathrm{C}$, whereas sample in the solid phase at $T=-5^{\circ} \mathrm{C}$. 

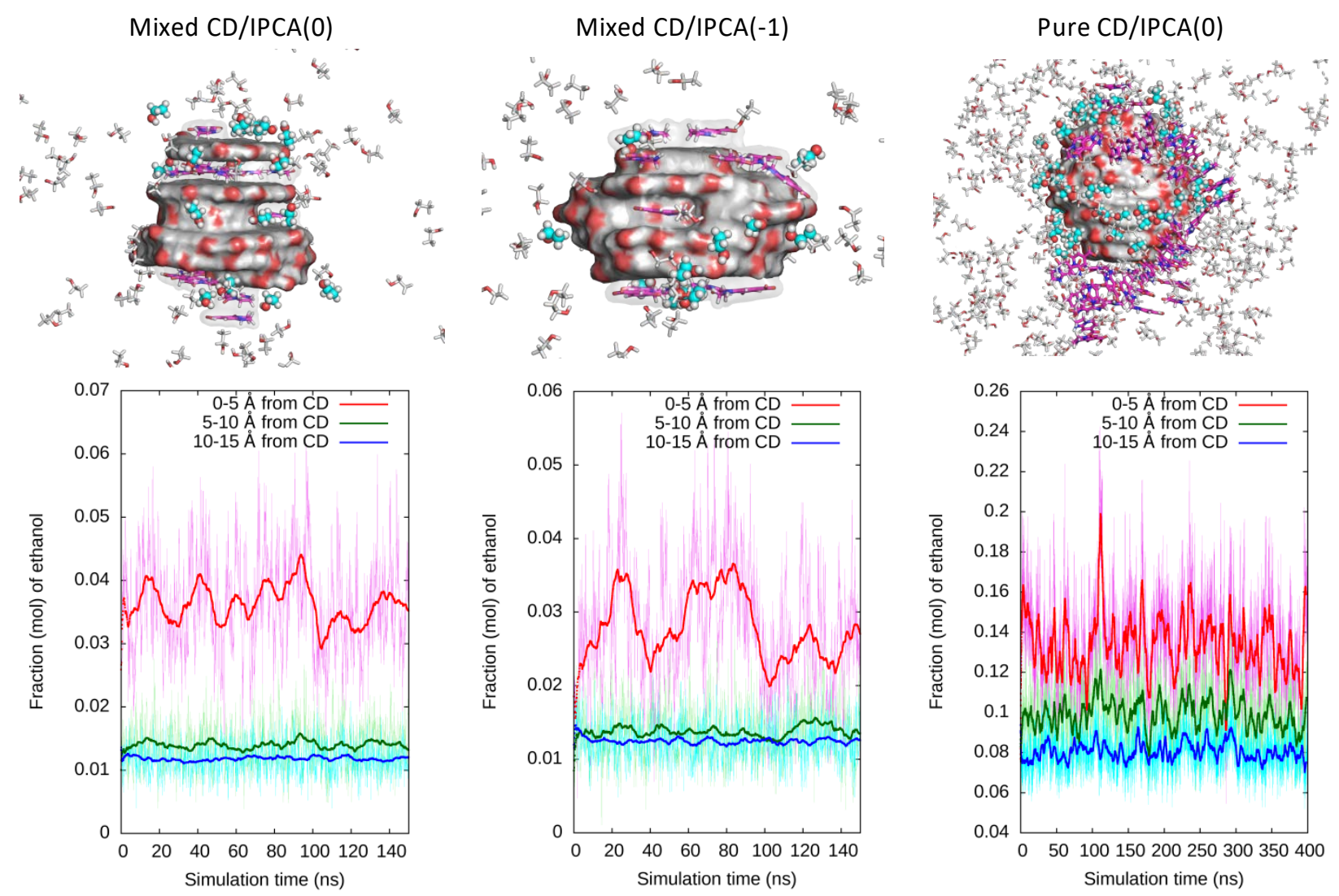

Figure S10. Snapshots from MD simulations showing ethanol molecules concentrated on the surface of a CD (upper panel). PAH layers at the surface are shown in grey/red, IPCA molecules (with charge states indicated (0 or -1)) are shown as magenta sticks, ethanol molecules in the bulk of solution - as white sticks, while ethanols within $5 \AA$ of PAH layers are shown as cyan balls. Further color coding: hydrogen - white, oxygen - red, nitrogen - blue. Water is omitted for clarity. Lower panel shows the evolution of molar fraction of ethanol within certain distance of a closest atom of PAH layer highlighting the increased fraction of ethanol in proximity of $C D$.

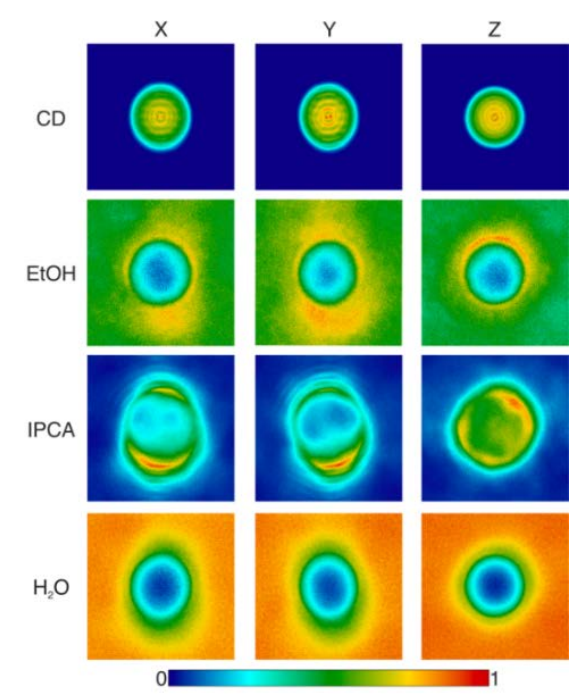

Figure S11. Normalized density maps of pure CD/IPCA(0) model, displaying the preferential spots where CD, IPCA, EtOH and $\mathrm{H}_{2} \mathrm{O}$ prefer to reside during $400 \mathrm{~ns}$ of the MD simulation. Cross-sections along three perpendicular $\mathrm{x}, \mathrm{y}, \mathrm{z}$ directions of view. Coloring scheme: the normalized density increases from blue to red color. 


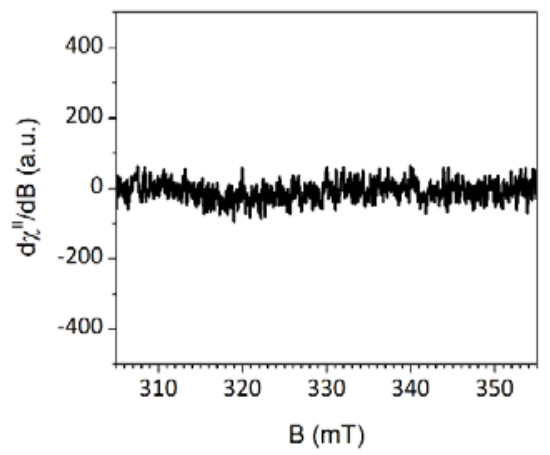

Figure S12. EPR envelope of CDs in water recorded without light illumination.
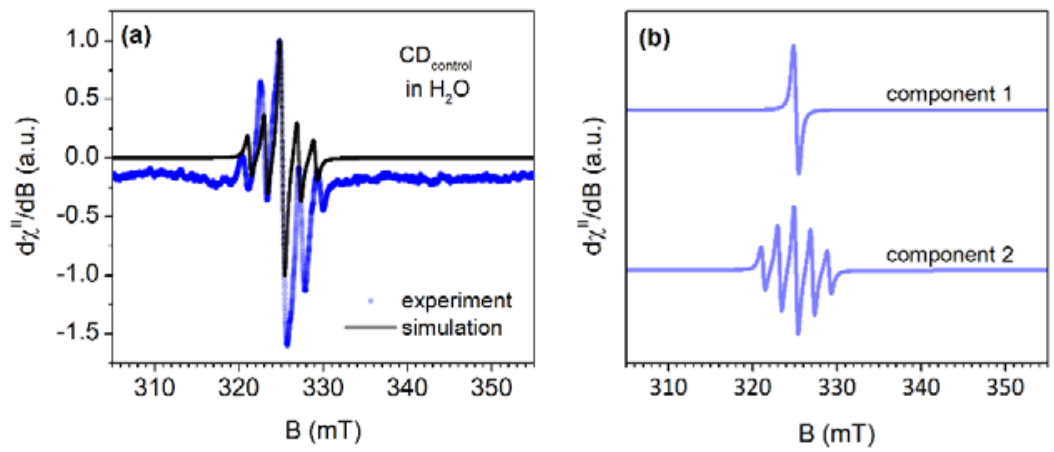

Figure S13. (a) LEPR envelope of $C D_{\text {control }}$ (without the presence of the molecular fluorophore) in water. (b) Corresponding individual components of simulations.
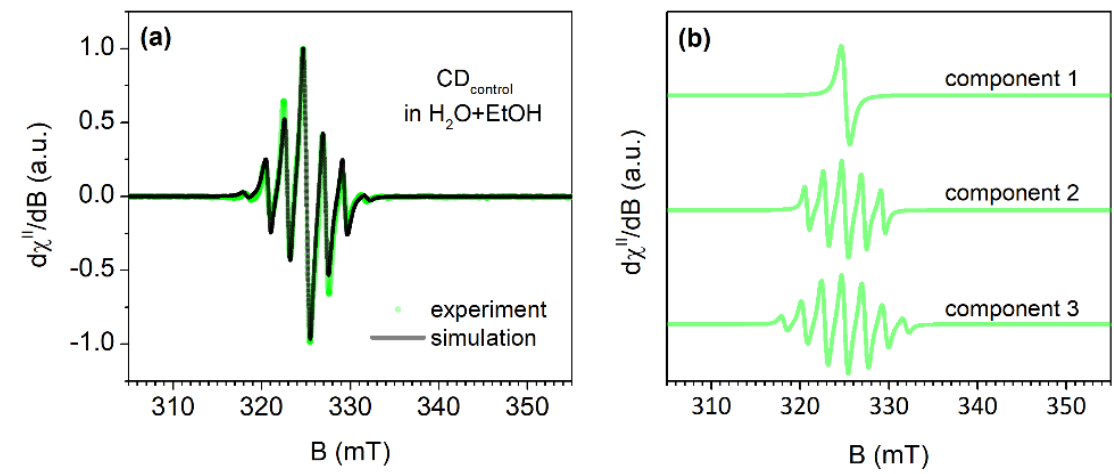

Figure S14. (a) LEPR envelope of $C D_{\text {control }}$ (without the presence of the molecular fluorophore) in a water-ethanol (50:50 vol \%) solution. (b) Corresponding individual components of simulations.
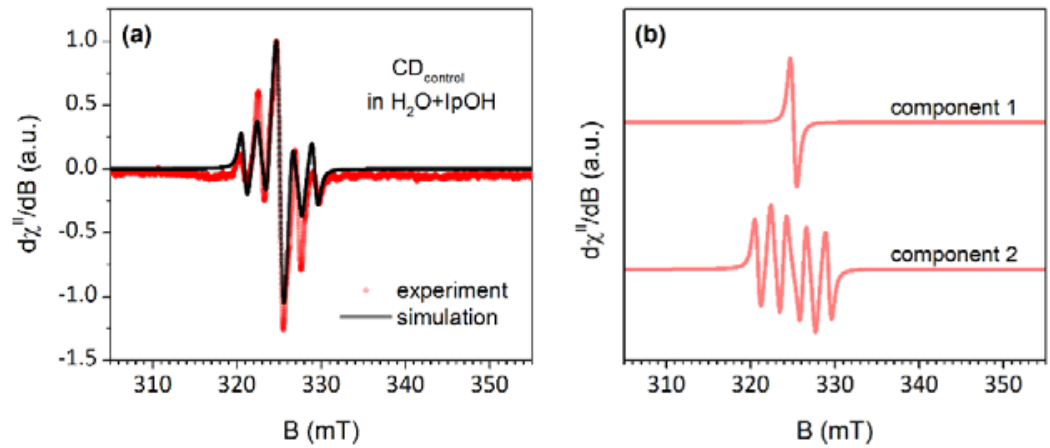

Figure S15. (a) LEPR envelope of $C_{\text {control }}$ (without the presence of the molecular fluorophore) in a water-2-propanol (50:50 vol \%) solution. (b) Corresponding individual components of simulations. 
Table S1. EPR parameters derived from simulations together with corresponding weights of individual components.

\begin{tabular}{|l|c|c|c|c|c|c|c|}
\hline & $g$ Core & $\mathbf{g}$ Shell & $\begin{array}{c}\text { Core } \\
\text { Weight, } \%\end{array}$ & $\begin{array}{c}\text { Shell Weight, } \\
\%\end{array}$ & $\begin{array}{c}\text { Anisotropy N1, } \\
\mathbf{M H z}\end{array}$ & $\begin{array}{c}\text { Anisotropy N2, } \\
\mathbf{M H z}\end{array}$ & $\begin{array}{c}\text { Anisotropy N3, } \\
\mathbf{M H z}\end{array}$ \\
\hline CDs in water & 1.9966 & 1.9965 & 25.4 & 74.6 & 54.82 & 54.56 & - \\
\hline $\begin{array}{l}\text { CDs in water/ethanol } \\
\text { (50:50 vol \%) }\end{array}$ & 1.9969 & 1.9971 & 37.2 & 62.8 & 61.08 & 60.85 & 60.67 \\
\hline $\begin{array}{l}\text { CDs in water/2-propanol } \\
\text { (50:50 vol \%) }\end{array}$ & 1.9963 & 1.9965 & 28.0 & 72.0 & 66.46 & 50.5808 & - \\
\hline
\end{tabular}
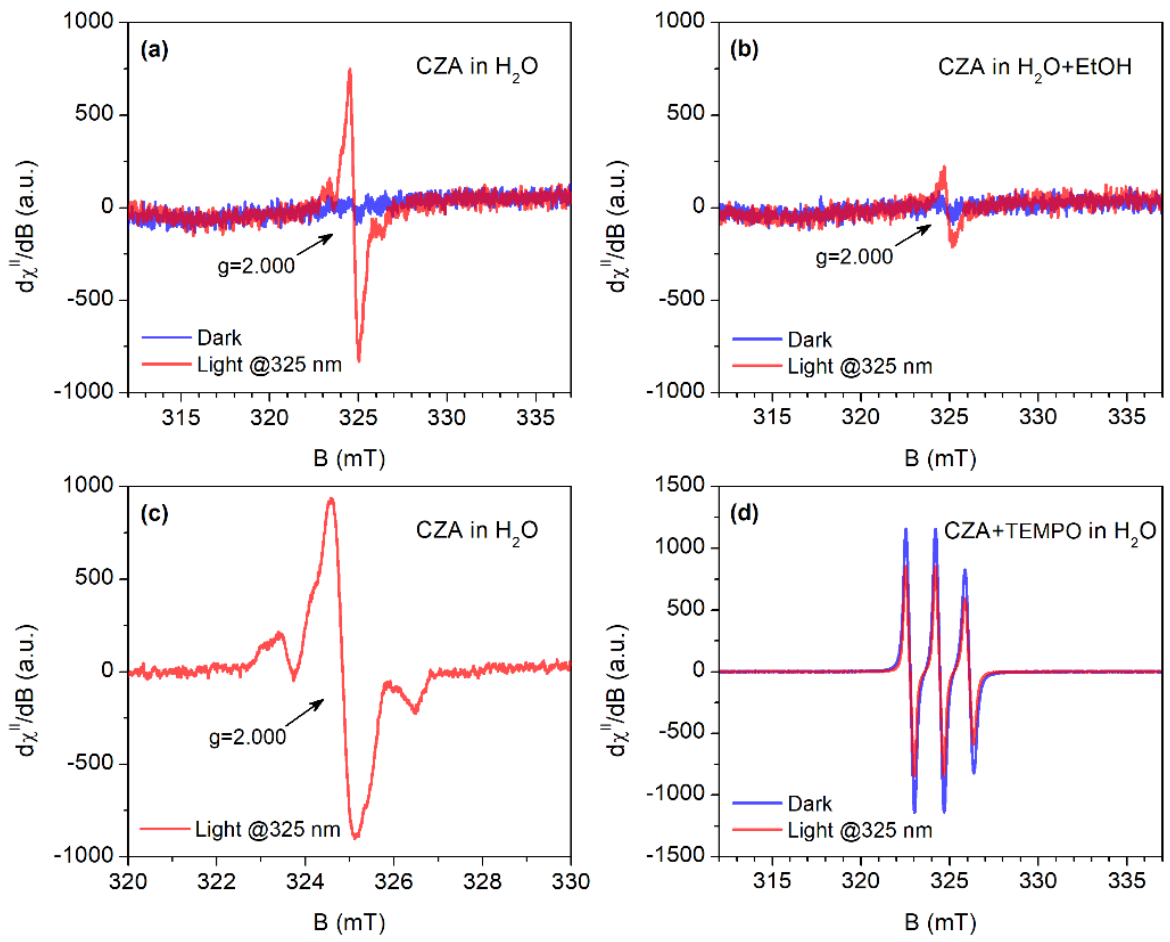

Figure S16. X-band EPR spectra obtained without (blue lines) and with in situ application of UV light ( $\lambda=325 \mathrm{~nm}$, red lines) on citrazinic acid (CZA, CAS number: 99-11-6; EC number: 202-731-2) suspended in water solution (a, c) or in waterethanol mixture (50:50 vol \%) (b) recorded at $T=90 \mathrm{~K}$. The concentration of CZA was $2 \mathrm{mg} / \mathrm{mL}$. Experimental parameters: $(a, b)$ microwave frequency $9.087-9.088 \mathrm{GHz}, 100 \mathrm{kHz}$ mod. frequency, $0.3 \mathrm{mT}$ modulation width, $2.00 \mathrm{~mW}$ applied microwave power, 2 min sweep time, 0.03 s time constant; (c) microwave frequency $9.090 \mathrm{GHz}, 100 \mathrm{kHz}$ mod. frequency, $0.3 \mathrm{mT}$ modulation width, $0.4 \mathrm{~mW}$ applied microwave power, $1 \mathrm{~min}$ sweep time, $0.03 \mathrm{~s}$ time constant, 11 scans accumulated and averaged. (d) X-band EPR spectra obtained without (blue line) and with in situ application of UV light $\lambda$ $=325 \mathrm{~nm}$, red line) of CZA in presence of TEMPO radical dispersed in water. Experimental parameters: microwave frequency $9.088 \mathrm{GHz}, 100 \mathrm{kHz}$ mod. frequency, $0.5 \mathrm{mT}$ modulation width, $0.9 \mathrm{~mW}$ applied microwave power, $1 \mathrm{~min}$ sweep time, $0.03 \mathrm{~s}$ time constant and $T=180 \mathrm{~K}$.

Note: In frozen water matrix upon light irradiation, CZA shows emergence of EPR resonances consistent with formation of spin active photoexcited species (Fig. S16a, red line). Close inspection of this EPR spectrum under UV light (Fig. S16c) suggests that those spin active specie arise from an admixture of triplets species and polaron pairs. This phenomenon appears to be favored by the high concentration used of CZA in solution. For the frozen water-EtOH solution recorded in the same conditions (Fig. S16b), only a very minor spin active species are formed upon excitation. Therefore, the exciton formed favors adoption of the singlet state. This phenomenon can be linked to the weakening/disruption of strong hydrogen bonding interactions among CZA molecules, which leads to formation of significant amount of dimers/trimers. ${ }^{3}$ Experiments conducted using the spin quenching TEMPO radical in water together with CZA (Fig. S16d) supports the former attribution, namely formation of admixture of spin active triplets/polaron pairs species in water, and shows a slight decrease of the radical signal upon light irradiation, due to its interaction with those spin active components. 

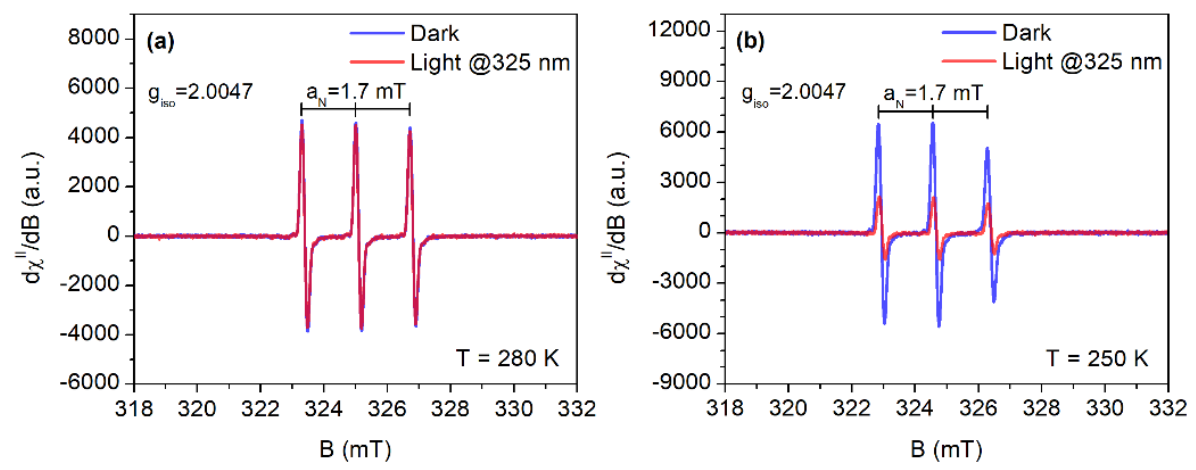

Figure S17. X-band EPR spectra obtained without (blue spectra) and during in situ application of UV light (@325 nm, orange spectra) on CDs dispersed in water solution containing 2,2,6,6-tetramethylpiperidine-1-oxyl (TEMPO) radical. (a) $T=280 \mathrm{~K}$, microwave frequency $9.1054 \mathrm{GHz}, 100 \mathrm{kHz}$ mod. frequency, $0.2 \mathrm{mT}$ modulation width, $1.0 \mathrm{~mW}$ applied microwave power, 2 min sweep time, $0.03 \mathrm{~s}$ time constant. (b) $T=250 \mathrm{~K}$, microwave frequency $9.0931 \mathrm{GHz}, 100 \mathrm{kHz}$ mod. frequency, $0.2 \mathrm{mT}$ modulation width, $0.4 \mathrm{~mW}$ applied microwave power, $2 \mathrm{~min}$ sweep time, $0.03 \mathrm{~s}$ time constant. Sample irradiation was carried out directly inside the EPR cavity resonator for 4-5 min before recording the resonance signals. The aqueous solutions containing CDs and TEMPO were thoroughly degassed inside the EPR tubes and kept under $\mathrm{N}_{2}$ during measurements (dark and under light irradiation).

Note: Figure S17a shows no quenching of the radical EPR signal upon light exposure at $T=280 \mathrm{~K}$, while in the frozen water matrix (Figure $\mathrm{S} 17 \mathrm{~b}, T=250 \mathrm{~K}$ ) the EPR signal associated with the TEMPO radical strongly decreases following light irradiation ( $67 \%$ decrease of the double integrated resonance signal). This process is thought to originate from the spin exchange interactions occurring between the photo-excited CD triplet $\left({ }^{3} \mathrm{~T}\right)$ and the TEMPO $(R \bullet)$ promoting vibrational relaxation of the triplet $\left({ }^{3} \mathrm{~T}\right)$ to the ground-state vibrational manifold. ${ }^{4}$

Table S2. Optimized parameters of the kinetic models described by Jablonski diagrams (Figure 4c,d) with uncertainties determined as the standard deviations (STD) of the mean values from 100 simulations with random initial guess within the given range of fitting parameters (rate constants are in $\mathrm{ns}^{-1}, \Delta G_{t}$ in $\mathrm{kcal} / \mathrm{mol}$ ). The sampling intervals for the radiative rate constant $\left(k_{r 1}\right)$ were derived from the experimentally determined values, i.e., $0.09,0.13$ and $0.09 \mathrm{~ns}^{-1}$ for water (I), ice (s) and water-ethanol (s), respectively. The fits were performed on the experimental data using the PL intensity threshold of $10^{-2}$ to eliminate a bias arising from more scattered data with PL intensity values below $10^{-2}$ which are measured with larger uncertainties.

\begin{tabular}{|c|c|c|c|}
\hline & Water (liquid) & Ice (solid) & Water-ethanol (solid) \\
\hline & $k_{r 1}, k_{n r 1}, k_{t f}, \Delta G_{t}, k_{x}$ & $k_{r 1}, k_{n r 1}, k_{t f}, \Delta G_{t}, k_{x}$ & $k_{r 1}, k_{n r 1}, k_{t f}, \Delta G_{t}, k_{x}$ \\
\hline Constraints & $\begin{array}{l}([0.08,0.001,0.001,-20.0, \\
0.0001], \\
[0.10,0.2,0.2,20.0,0.1])\end{array}$ & $\begin{array}{l}([0.10,0.001,0.001,-20.0 \\
0.00005], \\
[0.14,0.5,0.4,20.0,0.1])\end{array}$ & $\begin{array}{l}([0.08,0.001,0.001,-20.0 \\
0.0001], \\
[0.10,0.2,0.2,20.0,0.1])\end{array}$ \\
\hline $\begin{array}{l}\text { Optimized } \\
\text { parameters }\end{array}$ & $\begin{array}{l}{[0.084 \pm 0.003,0.030 \pm 0.008} \\
0.064 \pm 0.007,5.9 \pm 2.1 \\
0.025 \pm 0.011]\end{array}$ & $\begin{array}{l}{[0.129 \pm 0.010,0.393 \pm 0.024} \\
0.303 \pm 0.020,-0.1 \pm 1.4 \\
0.060 \pm 0.021]\end{array}$ & $\begin{array}{l}{[0.084 \pm 0.003,0.031 \pm 0.009} \\
0.068 \pm 0.009,5.7 \pm 2.2 \\
0.026 \pm 0.012]\end{array}$ \\
\hline
\end{tabular}




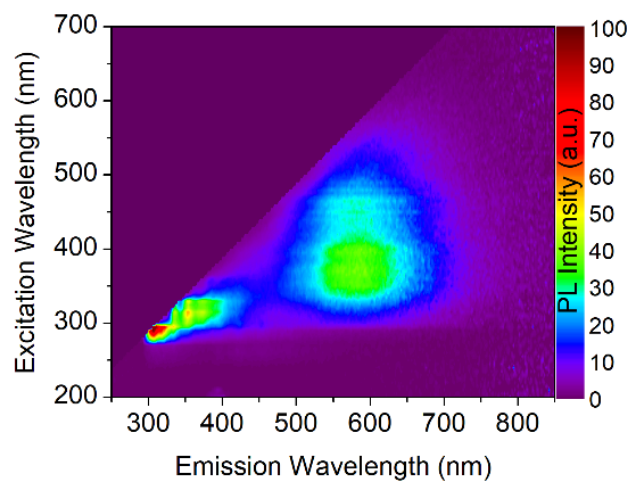

Figure S18. Excitation-emission color map of CDs at $T=117 \mathrm{~K}$ in solid (frozen) state.

Table S3. Vertical ionization potentials (IE) and electron affinities (EA) (in $\mathrm{kcal} / \mathrm{mol}$ ) of model species representing carbon core (coronene), hydrophilic surface (NP1-NP4), and IPCA (see structures in Figure S8) calculated at the CAM-B3LYP/augcc-pVTZ/CPCM level of theory using the geometries optimized at the CAM-B3LYP/6-31G(d)/CPCM (coronene) or taken from the literature: ref. 5 and ref. 6.

\begin{tabular}{lcccccc}
\hline \multirow{2}{*}{ Environment } & \multicolumn{2}{c}{ Water (I) } & \multicolumn{2}{c}{ Ice (I) $^{\mathrm{a}}$} & \multicolumn{2}{c}{ Differences } \\
\hline System & IE & EA & IE & EA & $\Delta \mathrm{IE}$ & $\Delta \mathrm{EA}$ \\
\hline coronene & 136.7 & 44.0 & 136.5 & 44.3 & -0.2 & 0.3 \\
NP1 & 96.1 & 45.1 & 95.8 & 45.4 & -0.3 & 0.3 \\
NP2 & 91.7 & 53.0 & 91.4 & 53.2 & -0.3 & 0.2 \\
NP3 & 90.4 & 60.3 & 90.1 & 60.6 & -0.3 & 0.3 \\
NP4 & 89.3 & 52.2 & 89.1 & 52.5 & -0.2 & 0.3 \\
IPCA & 134.1 & 51.5 & 133.8 & 51.8 & -0.3 & 0.3 \\
\hline
\end{tabular}

alce was treated within the CPCM model by the change of relative permittivity of water from 78.4 to 171.0 .

Table S4. Estimated relative energies $(\triangle E c T)$ of the $\left[D^{+} \ldots A^{-}\right]$state (with respect to the ground state) computed as the difference of IE of a donor and EA of an acceptor (IE(D) - EA(A)) taken from Table S3.

\begin{tabular}{llcccc}
\hline \multirow{2}{*}{ Donor } & \multirow{2}{*}{ Acceptor } & \multicolumn{2}{c}{$\Delta E_{\text {ct }}(\mathbf{k c a l} / \mathbf{m o l})$} & \multicolumn{2}{c}{$\Delta E_{\text {ct }}(\mathbf{e V})$} \\
& & Water & Ice & Water & Ice \\
\hline NP1 & coronene & 52.1 & 51.5 & 2.26 & 2.23 \\
NP2 & coronene & 47.7 & 47.1 & 2.07 & 2.04 \\
NP3 & coronene & 46.4 & 45.8 & 2.01 & 1.99 \\
NP4 & coronene & 45.3 & 44.8 & 1.96 & 1.94 \\
IPCA & coronene & 90.1 & 89.5 & 3.91 & 3.88 \\
NP1 & IPCA & 44.6 & 44.0 & 1.93 & 1.91 \\
coronene & NP1 & 91.6 & 91.1 & 3.97 & 3.95 \\
\hline
\end{tabular}


Table S5. Fitting parameters of PL lifetime $(\tau)$, stretching parameter $(\beta)$, and goodness of fit $\left(\chi^{2}\right)$ for PL decays of CDs in mixtures of water-ethanol for different concentrations of ethanol (Figure 5). The PL decays were fitted using a stretched exponential function: $I(t)=I_{0} e^{-(t / \tau)^{\beta}}$, where the fit parameters $\tau$ and $\beta$ are the PL decay time and stretch parameter, respectively.

\begin{tabular}{lccccccc}
\hline $\begin{array}{c}\text { EtOH Concentration } \\
\text { (vol \%) }\end{array}$ & \multicolumn{3}{c}{ Water (Liquid) } & \multicolumn{3}{c}{ Ice (Solid) } \\
& $\boldsymbol{\tau}$ (ns) & $\boldsymbol{\beta}$ & $\boldsymbol{\chi}^{\mathbf{2}}$ & $\boldsymbol{\tau}$ (ns) & $\boldsymbol{\beta}$ & $\boldsymbol{\chi}^{\mathbf{2}}$ \\
\hline 50 & 5.585 & 0.719 & 1.011 & 5.687 & 0.682 & 1.104 \\
20 & 5.976 & 0.711 & 1.021 & 5.168 & 0.660 & 1.261 \\
5 & 5.891 & 0.712 & 1.105 & 5.488 & 0.683 & 1.080 \\
1 & 5.812 & 0.707 & 1.044 & 5.768 & 0.704 & 1.101 \\
0.5 & 5.363 & 0.696 & 1.236 & 5.311 & 0.667 & 1.243 \\
0.1 & 5.718 & 0.702 & 0.966 & 5.655 & 0.697 & 1.098 \\
0.01 & 5.669 & 0.701 & 1.005 & 4.702 & 0.662 & 1.270 \\
0.0067 & 5.315 & 0.721 & 1.108 & 3.346 & 0.691 & 1.054 \\
0.0033 & 5.304 & 0.714 & 1.027 & 2.634 & 0.647 & 1.195 \\
0.001 & 5.636 & 0.700 & 1.094 & 1.860 & 0.591 & 1.069 \\
0.0001 & 5.666 & 0.717 & 0.960 & 1.295 & 0.622 & 1.293 \\
\hline
\end{tabular}

Wavelength $(\mathrm{nm})$

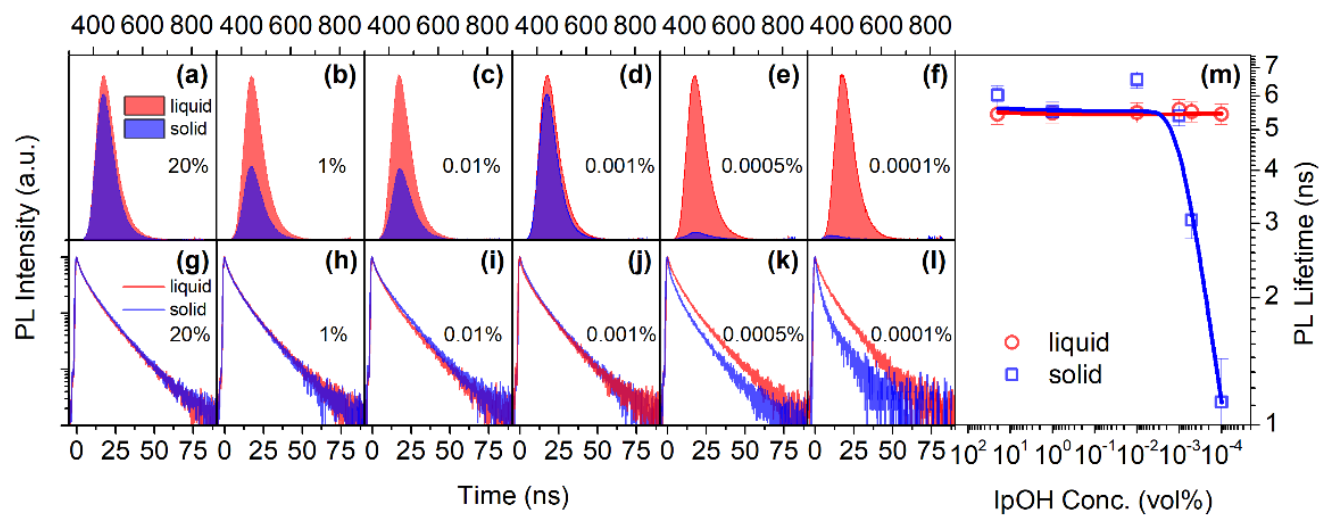

Figure S19. Emission properties of $\mathrm{CDs}$ as a function of solvent composition (water-2-propanol) for different concentrations of 2-propanol (in vol \%). (a-e) PL emission spectra and (f-j) PL decay curves of CDs in water-2-propanol mixtures of different concentrations of 2-propanol in liquid (shown in red) and solid (ice, shown in blue) phases. The samples in the solid phase were measured at the temperature set at $10^{\circ} \mathrm{C}$ below the freezing point of each mixture to make sure that phase transition had completed. (k) PL lifetimes of CDs in liquid and solid phases as a function of 2propanol concentration in water-2-propanol mixtures. 
Wavelength $(\mathrm{nm})$

400600800400600800400600800400600800400600800400600800

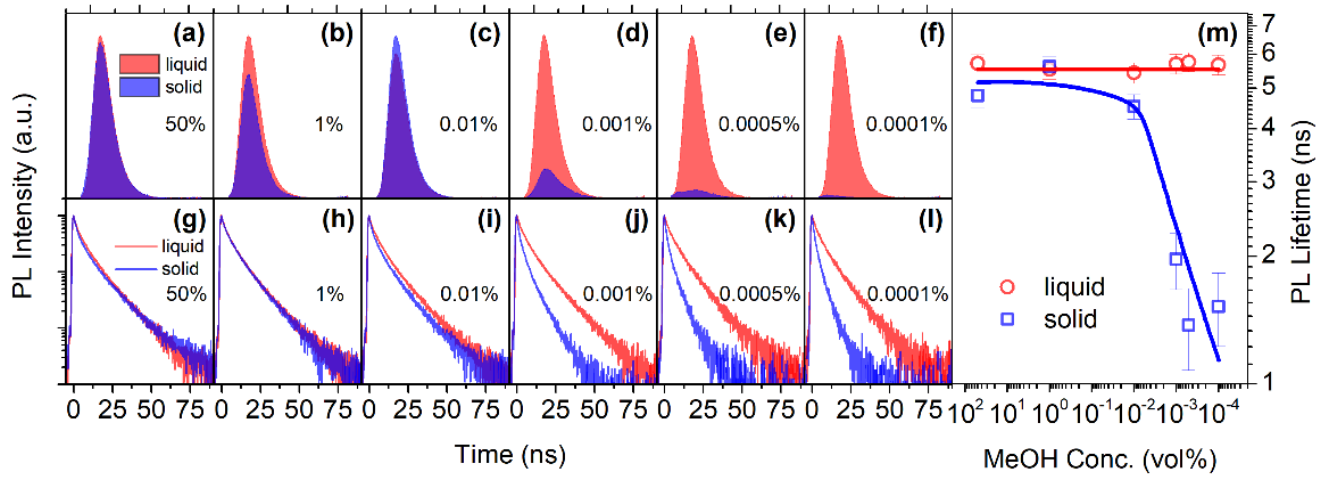

Figure S20. Emission properties of $\mathrm{CDs}$ as a function of solvent composition (water-methanol) for different concentrations of methanol (in vol \%). (a-e) PL emission spectra and (f-j) PL decay curves of CDs in water-methanol mixtures of different concentrations of methanol in liquid (shown in red) and solid (ice, shown in blue) phases. The samples in the solid phase were measured at the temperature set at $10^{\circ} \mathrm{C}$ below the freezing point of each mixture to make sure that phase transition had completed. (k) PL lifetimes of CDs in liquid and solid phases as a function of methanol concentration in water-methanol mixtures.

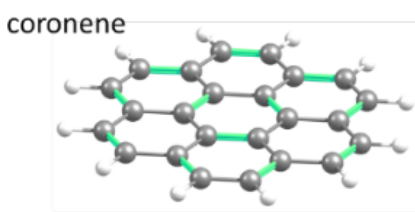

NP1
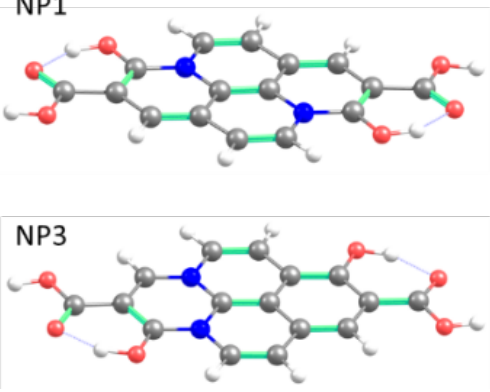
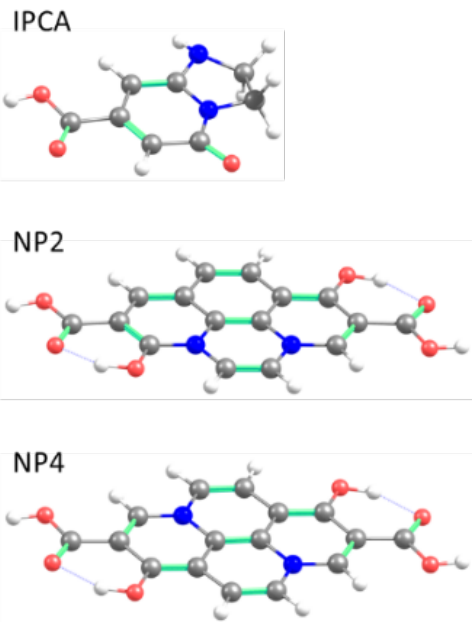

Figure S21. Structures of model species representing carbon core (coronene), hydrophilic surface (NP1-NP4), and IPCA molecule. The structure of coronene was optimized at the CAM-B3LYP/6-31G(d)/CPCM(solvent=water) level of theory, the structures of NP1-NP4 and IPCA were taken from ref. 5 and 6, respectively. 


\section{Relations between Kinetic Parameters Used in the Model Applied}

The relations between the kinetic parameters used in the general model involving the ${ }^{1}\left[D^{+} \ldots A^{-}\right]$ and ${ }^{3}\left[D^{+} \ldots A^{-}\right]$states and the simplified model (Figure 4 ) can be derived. Equilibrium constants for equilibria ${ }^{1}\left[D^{*} \ldots A\right] \leftrightarrow{ }^{1}\left[D^{+} \ldots A^{-}\right],{ }^{1}\left[D^{+} \ldots A^{-}\right] \leftrightarrow{ }^{3}\left[D^{+} \ldots A^{-}\right]$, and ${ }^{1}\left[D^{*} \ldots A\right] \leftrightarrow\left[D^{+} \ldots A^{-}\right]_{\text {trap }}$, can respectively be expressed in terms of equilibrium concentrations, rate constants and Gibbs energy differences as follows:

$$
\begin{aligned}
& K_{2}=\frac{\left[{ }^{1}\left[\mathrm{D}^{+\cdots} \mathrm{A}^{-}\right]\right]}{\left[{ }^{1}\left[\mathrm{D}^{*} \cdots \mathrm{A}\right]\right]}=\frac{k_{2 f}}{k_{2 b}}=e^{-\frac{\Delta G_{2}}{R T}} \\
& K_{3}=\frac{\left[{ }^{3}\left[\mathrm{D}^{+} \cdots \mathrm{A}^{-}\right]\right]}{\left[{ }^{1}\left[\mathrm{D}^{+\cdots} \mathrm{A}^{-}\right]\right]}=\frac{k_{3 f}}{k_{3 b}}=e^{-\frac{\Delta G_{S-T}}{R T}} \\
& K_{t}=\frac{\left[\left[\mathrm{D}^{+\cdots} \mathrm{A}^{-}\right]_{\text {trap }}\right]}{\left[{ }^{1}\left[\mathrm{D}^{*} \cdots \mathrm{A}\right]\right]}=\frac{k_{t f}}{k_{t b}}=e^{-\frac{\Delta G_{t}}{R T}}
\end{aligned}
$$

Since the ${ }^{3}\left[D^{+} \ldots A^{-}\right]$state is more stable than ${ }^{1}\left[D^{+} \ldots A^{-}\right]$, it is more populated, and thus we can write:

$$
\begin{aligned}
& K_{t}=\frac{\left[\left[\mathrm{D}^{+} \cdots \mathrm{A}^{-}\right]_{t r a p}\right]}{\left[{ }^{1}\left[\mathrm{D}^{*} \cdots \mathrm{A}\right]\right]} \cong \frac{\left[{ }^{3}\left[\mathrm{D}^{+} \cdots \mathrm{A}^{-}\right]\right]}{\left[{ }^{1}\left[\mathrm{D}^{*} \cdots \mathrm{A}\right]\right]}=K_{2} \cdot K_{3} \\
& \frac{k_{t f}}{k_{t b}} \cong \frac{k_{2 f}}{k_{2 b}} \cdot \frac{k_{3 f}}{k_{3 b}} \\
& \Delta G_{t} \cong \Delta G_{2}+\Delta G_{S-T}
\end{aligned}
$$




\section{Molecular Dynamics Simulations}

For molecular dynamics (MD) simulations we used IPCA molecules described by a GAFF force field as published in our previous paper ${ }^{6}$ (the topology of the anionic form is provided at the end of this Supporting Information). Structures of CDs were modelled with carbon dot builder (2.9 $\mathrm{nm}$ in diameter) ${ }^{7}$, with individual polycyclic aromatic hydrocarbon (PAH) layers that were functionalized on $30 \%$ of their edges by hydroxyl groups. CDs were parameterized in an AMBER ff99 force field ${ }^{8}$ with Cheng \& Steele carbons ${ }^{9}$. Further, we used CDs made by spontaneous self-assembly of 15 IPCA molecules within six PAH layers. The systems were solvated with different concentrations of ethanol ${ }^{10-11}$, SPC/E water model ${ }^{12}$, ions ${ }^{13}$ and in the case of no IPCAs embedded in the CD structure, IPCA molecules were added to the solvent as well (see Table S6 for system compositions). After minimization (steepest descent algorithm), MD simulations were performed under NpT conditions, using a 2 fs time step and bonds involving hydrogens were constrained with the LINCS algorithm ${ }^{14}$. A V-rescale thermostat ${ }^{15}$ was used to keep the temperature at $300 \mathrm{~K}$ with a $0.1 \mathrm{ps}$ scaling constant. Pressure was kept at 1 bar with the isotropic Berendsen ${ }^{16}$ barostat; the time constant for pressure relaxation was set to 2.0 ps. Particle-mesh Ewald (PME) ${ }^{17}$ was used for treating the electrostatic interactions with a real-space cutoff of $1.0 \mathrm{~nm}$, the same cutoff was applied for van der Waals interactions. The periodic boundary conditions were applied in all three dimensions. MD simulations were performed by GROMACS 4.5 .1 and 5.0 versions $^{18}$.

Table S6. Composition of MD simulation boxes with number of PAH layers, charged and uncharged IPCA molecules, water, and ethanol molecules.

\begin{tabular}{|l|c|c|c|c|c|c|}
\hline & $\begin{array}{c}\text { Number of } \\
\text { PAH layers }\end{array}$ & \#IPCA(-1) & \#IPCA (0) & \#waters & \#ethanol & $\begin{array}{c}\text { Simulation } \\
\text { time (ns) }\end{array}$ \\
\hline \multirow{2}{*}{ Mixed CD/IPCA } & 6 & 15 & & 7779 & 100 & 150 \\
\cline { 2 - 7 } & 6 & & 15 & 7797 & 100 & 150 \\
\hline Pure CD & 9 & & 50 & 8277 & 642 & 400 \\
\hline
\end{tabular}




\section{Topology of IPCA Anion}

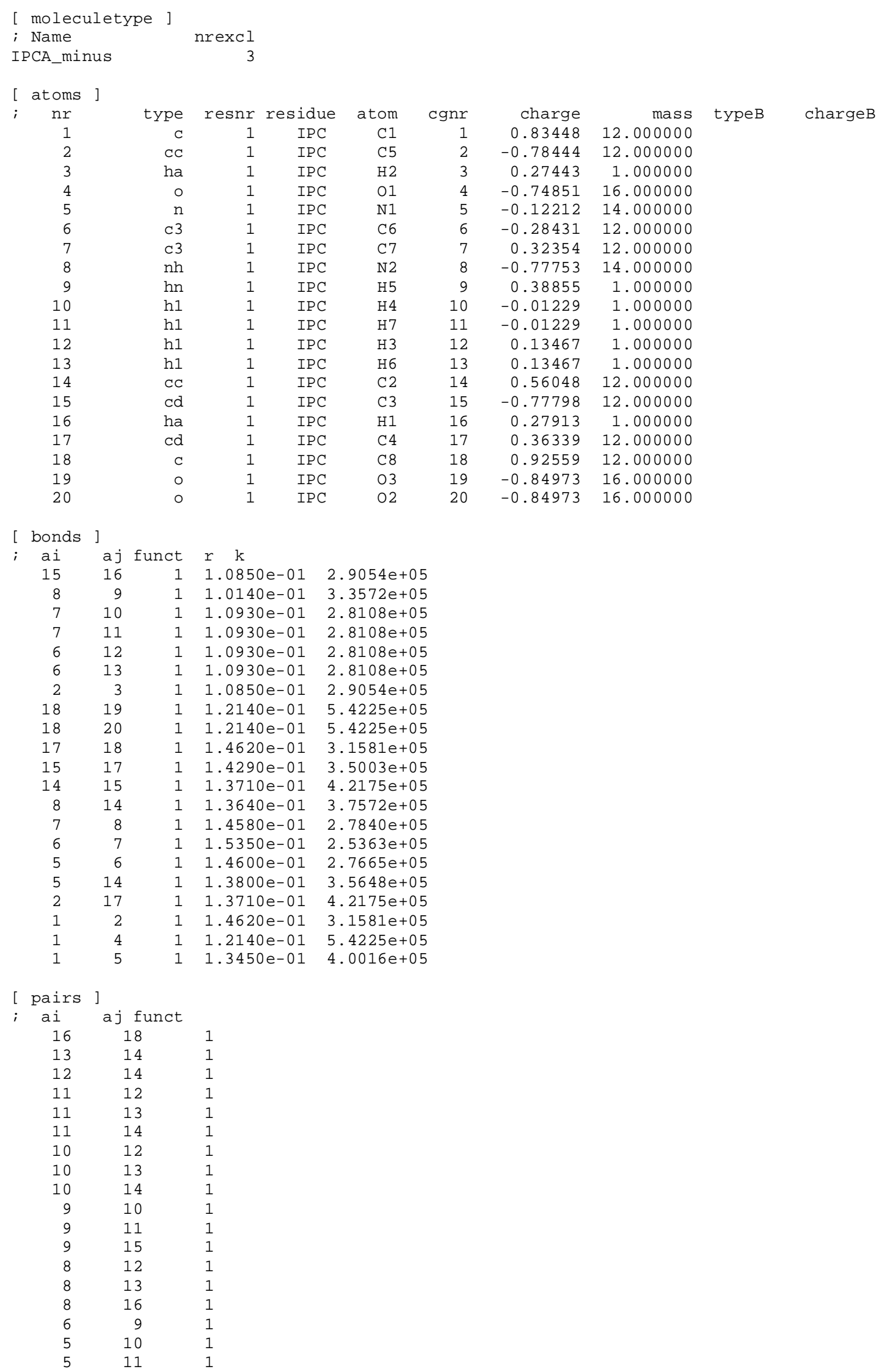




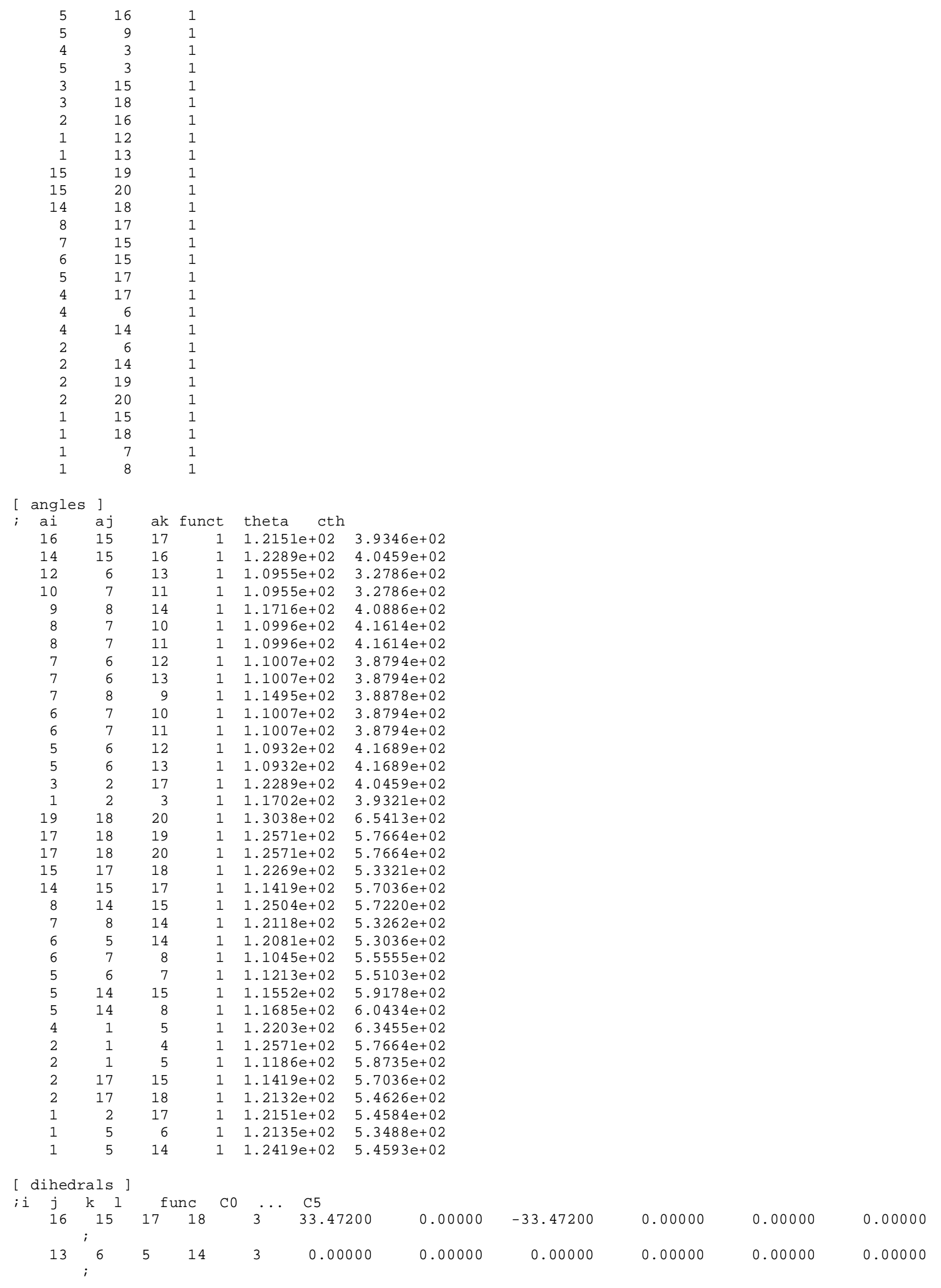




\begin{tabular}{|c|c|c|c|c|c|c|c|c|c|c|}
\hline 12 & 6 & 5 & 14 & 3 & $\odot . \odot \odot \odot \odot \odot$ & $\odot . \odot \odot \odot \odot \odot$ & $\odot .00 \odot \odot \odot$ & $\odot . \odot \odot \odot \odot \odot$ & $\odot .00000$ & 0.00000 \\
\hline 11 & 7 & 6 & 12 & 3 & 0.65270 & 1.95811 & $\odot .00000$ & -2.61082 & $\odot .000 \odot \odot$ & 0.00000 \\
\hline 11 & 7 & 6 & 13 & 3 & 0.65270 & 1.95811 & $\odot . ๑ \odot \odot \odot \odot$ & -2.61082 & $\odot . ๑ \odot \odot \odot \odot$ & 0.00000 \\
\hline 11 & 7 & 8 & 14 & 3 & $\odot . ๑ \odot \odot \odot \odot$ & $\odot . ๑ \odot \odot \odot \odot$ & ๑.๑७७९९ & ๑.๑०७७९ & $\odot .00 \odot \odot \odot$ & $\odot .00000$ \\
\hline 10 & $i_{7}$ & 6 & 12 & 3 & $\odot .65270$ & 1.95811 & $\odot .00 \odot \odot \odot$ & -2.61082 & $\odot . ๑ \odot \odot \odot \odot$ & 0.00000 \\
\hline 10 & 7 & 6 & 13 & 3 & $\odot .65270$ & 1.95811 & ๑.००००० & -2.61082 & $\odot .0 \odot \odot \odot \odot$ & $\odot .0000 \odot$ \\
\hline 10 & 7 & 8 & 14 & 3 & $\odot . ๑ \odot ० \odot \odot$ & 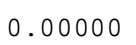 & ๑.๑७९७९ & ๑.๑०७७९ & ๑.๑०००९ & 0.00000 \\
\hline 9 & 8 & 7 & 10 & 3 & $\odot .0000 \odot$ & $\odot .0 \odot ० ० \odot$ & $\odot . ๑ \odot \odot \odot \odot$ & $\odot . ๑ \odot \odot \odot \odot$ & $\odot .00 \odot \odot \odot$ & $\odot .0000 \odot$ \\
\hline 9 & 8 & 7 & 11 & 3 & $\odot .0000 \odot$ & $\odot .0000 \odot$ & $\odot . ๑ \odot \odot \odot \odot$ & $\odot . ๑ \odot \odot \odot \odot$ & $\odot .00 \odot \odot \odot$ & 0.00000 \\
\hline 9 & 8 & 14 & 15 & 3 & 8.78640 & $\odot .0000 \odot$ & -8.78640 & $\odot . ๑ \odot \odot ० \odot$ & $\odot .00 \odot \odot \odot$ & 0.00000 \\
\hline 8 & 7 & 6 & 12 & 3 & 0.65270 & 1.95811 & 0.00000 & -2.61082 & $\odot .00000$ & 0.00000 \\
\hline 8 & 7 & 6 & 13 & 3 & 0.65270 & 1.95811 & $\odot . ๑ \odot \odot \odot \odot$ & -2.61082 & $\odot . ๑ \odot \odot \odot \odot$ & $\odot .000 \odot \odot$ \\
\hline 8 & 14 & 15 & 16 & 3 & 33.47200 & $\odot .0000 \odot$ & -33.47200 & $\odot .00 \odot \odot \odot$ & $\odot . ๑ \odot \odot \odot \odot$ & $\odot .00000$ \\
\hline 6 & 7 & 8 & 9 & 3 & 0.00000 & $\odot .0 \odot ० ० \odot$ & 0.00000 & 0.00000 & 0.00000 & 0.00000 \\
\hline 5 & 6 & 7 & 10 & 3 & 0.65270 & 1.95811 & ๑.๑०९७९ & -2.61082 & $\odot . ๑ \odot ० \odot \odot$ & 0.00000 \\
\hline 5 & 6 & 7 & 11 & 3 & 0.65270 & 1.95811 & $\odot .00000$ & -2.61082 & $\odot .0 \odot \odot \odot \odot$ & $\odot .0000 \odot$ \\
\hline 5 & 14 & 15 & 16 & 3 & 33.47200 & $\odot .0000 \odot$ & -33.47200 & ๑.๑०७७९ & $\odot . ๑ \odot \odot \odot \odot$ & $\odot .0000 \odot$ \\
\hline 5 & 14 & 8 & 9 & 3 & 8.78640 & $\odot .0000 \odot$ & -8.78640 & $\odot . ๑ \odot \odot \odot \odot$ & $\odot . ๑ \odot \odot \odot \odot$ & $\odot .0000 \odot$ \\
\hline 4 & 1 & 2 & 3 & 3 & 24.05800 & $\odot .0 \odot ० ० \odot$ & -24.05800 & $\odot .0 \odot \odot \odot \odot$ & $\odot .00000$ & $\odot .0000 \odot$ \\
\hline 5 & 1 & 2 & 3 & 3 & 24.05800 & $\odot . ๑ \odot ० \odot \odot$ & -24.05800 & $\odot .00 \odot \odot \odot$ & $\odot . ๑ \odot \odot \odot \odot$ & $\odot .00000$ \\
\hline 3 & 2 & 17 & 15 & 3 & 33.47200 & $\odot .0 \odot ० ० \odot$ & -33.47200 & $\odot . ๑ \odot \odot \odot \odot$ & $\odot .0 \odot \odot \odot \odot$ & $\odot .00000$ \\
\hline 3 & 2 & 17 & 18 & 3 & 33.47200 & $\odot .0 \odot \odot \odot \odot$ & -33.47200 & $\odot . ๑ \odot \odot \odot \odot$ & $\odot .0 \odot \odot \odot \odot$ & $\odot .0000 \odot$ \\
\hline 2 & 17 & 15 & 16 & 3 & 33.47200 & $\odot . \odot \odot ० \odot \odot$ & -33.47200 & $\odot . \odot \odot \odot \odot \odot$ & $\odot . \odot \odot \odot \odot \odot$ & 0.00000 \\
\hline 1 & 5 & 6 & 12 & 3 & $\odot .0000 \odot$ & $\odot .0000 \odot$ & $\odot . ๑ \odot \odot \odot \odot$ & $\odot . ๑ \odot \odot \odot \odot$ & $\odot . ๑ \odot \odot \odot \odot$ & $\odot .0000 \odot$ \\
\hline 1 & 5 & 6 & 13 & 3 & $\odot .000 \odot \odot$ & $\odot . \odot ० ० ० \odot$ & $\odot . ๑ \odot \odot \odot \odot$ & $\odot .00 \odot \odot \odot$ & $\odot .00000$ & 0.00000 \\
\hline 15 & 17 & 18 & 19 & 3 & 24.05800 & $\odot . \odot \odot \odot \odot \odot$ & -24.05800 & ๑.00000 & ๑.00000 & $\odot .0 \odot \odot \odot \odot$ \\
\hline 15 & 17 & 18 & 20 & 3 & 24.05800 & $\odot . ๑ \odot \odot \odot \odot$ & -24.05800 & $\odot . \odot \odot \odot \odot \odot$ & $\odot . \odot \odot \odot \odot \odot$ & 0.00000 \\
\hline 14 & 15 & 17 & 18 & 3 & 33.47200 & $\odot .0000 \odot$ & -33.47200 & $\odot . ๑ \odot \odot \odot \odot$ & $\odot .0 \odot \odot \odot \odot$ & $\odot .00000$ \\
\hline 8 & 14 & 15 & 17 & 3 & 33.47200 & $\odot .0 \odot ० ० \odot$ & -33.47200 & $\odot . ๑ \odot \odot \odot \odot$ & $\odot . ๑ \odot \odot \odot \odot$ & 0.00000 \\
\hline 7 & 6 & 5 & 14 & 3 & 0.00000 & ๑.0०0०० & ๑.๑०००० & $\odot . \odot \odot \odot \odot \odot$ & ๑. $0000 \odot$ & $\odot .0000 \odot$ \\
\hline 7 & 8 & 14 & 15 & 3 & 8.78640 & $\odot .00000$ & -8.78640 & $\odot .00 \odot ० \odot$ & $\odot .00000$ & $\odot .00000$ \\
\hline 6 & 5 & 14 & 15 & 3 & 13.80720 & $\odot .00000$ & -13.80720 & $\odot .0000 \odot$ & $\odot . ๑ \odot \odot \odot \odot$ & 0.00000 \\
\hline 6 & 5 & 14 & 8 & 3 & 13.80720 & $\odot .0 ० ० ० \odot$ & -13.80720 & $\odot .0000 \odot$ & $\odot .0 \odot ० ० \odot$ & $\odot .0000 \odot$ \\
\hline 6 & 7 & 8 & 14 & 3 & $\odot .000 \odot \odot$ & $\odot .0 \odot \odot ० \odot$ & $\odot .0000 \odot$ & $\odot . ๑ \odot \odot \odot \odot$ & $\odot .00000$ & $\odot .00000$ \\
\hline 5 & $i_{1}$ & 2 & 17 & 3 & 24.05800 & ๑.๑०७०७ & -24.05800 & $\odot . ๑ \odot \odot \odot \odot$ & 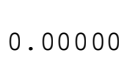 & $\odot .00000$ \\
\hline 5 & 6 & 7 & 8 & 3 & 0.65270 & 1.95811 & 0.00000 & -2.61082 & $\odot . ๑ \odot \odot \odot \odot$ & $\odot .00 \odot \odot \odot$ \\
\hline 5 & 14 & 15 & 17 & 3 & 33.47200 & ๑.००००० & -33.47200 & ๑.๑०७०९ & ๑.๑०००० & 0.00000 \\
\hline
\end{tabular}




\begin{tabular}{|c|c|c|c|c|c|c|c|c|c|c|}
\hline 5 & 14 & 8 & 7 & 3 & 8.78640 & $\odot .0 \odot \odot \odot \odot$ & -8.78640 & $\odot . \odot \odot \odot \odot \odot$ & $\odot . ๑ \odot \odot \odot \odot$ & $\odot .00 \odot \odot \odot$ \\
\hline 4 & 1 & 2 & 17 & 3 & 24.05800 & $\odot .0 \odot \odot \odot \odot$ & -24.05800 & $\odot .00000$ & $\odot . ๑ \odot \odot \odot \odot$ & $\odot .0000 \odot$ \\
\hline 4 & 1 & 5 & 6 & 3 & 20.92000 & $\odot . \odot \odot \odot \odot \odot$ & -20.92000 & $\odot . ๑ \odot \odot \odot \odot$ & $\odot . ๑ \odot \odot \odot \odot$ & $\odot .0000 \odot$ \\
\hline 4 & 1 & 5 & 14 & 3 & $20.920 \odot \odot$ & $\odot . \odot \odot \odot \odot \odot$ & -20.92000 & $\odot . \odot \odot \odot \odot \odot$ & $\odot . \odot \odot \odot \odot \odot$ & $\odot .000 \odot \odot$ \\
\hline 2 & 1 & 5 & 6 & 3 & 20.92000 & $\odot .0 \odot \odot \odot \odot$ & -20.92000 & $\odot .000 \odot \odot$ & $\odot .0 \odot \odot \odot \odot$ & $\odot .0000 \odot$ \\
\hline 2 & 1 & 5 & 14 & 3 & 20.92000 & $\odot .0 \odot \odot \odot \odot$ & -20.92000 & $\odot . \odot \odot \odot \odot \odot$ & $\odot . \odot \odot \odot \odot \odot$ & $\odot .0000 \odot$ \\
\hline 2 & 17 & 15 & 14 & 3 & 33.47200 & $\odot .0 \odot \odot ० \odot$ & -33.47200 & $\odot . \diamond \odot \odot \odot \odot$ & $\odot . \diamond \odot \odot \odot \odot$ & 0.00000 \\
\hline 2 & 17 & 18 & 19 & 3 & $24.0580 \odot$ & $\odot . \odot \odot \odot \odot \odot$ & -24.05800 & $\odot . \odot \odot \odot \odot \odot$ & $\odot . ๑ \odot \odot \odot \odot$ & $\odot . \odot \odot \odot \odot \odot$ \\
\hline 2 & 17 & 18 & 20 & 3 & 24.05800 & $\odot .0000 \odot$ & -24.05800 & $\odot . \diamond \odot \odot \odot \odot$ & $\odot .000 \diamond \odot$ & 0.00000 \\
\hline 1 & 2 & 17 & 15 & 3 & 33.47200 & $\odot . \odot \odot \odot \odot \odot$ & -33.47200 & $\odot . ๑ \odot \odot \odot \odot$ & $\odot . ๑ \odot \odot \odot \odot$ & $\odot .0000 \odot$ \\
\hline 1 & 2 & 17 & 18 & 3 & 33.47200 & $\odot .0 \odot \odot \odot \odot$ & -33.47200 & $\odot . \odot \odot \odot \odot \odot$ & $\odot . \odot \odot \odot \odot \odot$ & $\odot .000 \odot \odot$ \\
\hline 1 & 5 & 6 & 7 & 3 & 2.84512 & -4.10032 & 16.73600 & 2.51040 & -16.73600 & $\odot . ๑ \odot \odot \odot \odot$ \\
\hline 1 & 5 & 14 & 15 & 3 & 13.80720 & $\odot . \odot \odot \odot \odot \odot$ & -13.80720 & $\odot .000 \bullet \odot$ & $\odot . \diamond \odot \odot \odot \odot$ & $\odot . \odot \odot \odot \odot \odot$ \\
\hline 1 & 5 & 14 & 8 & 3 & 13.80720 & $\odot . \odot \odot \odot \odot \odot$ & -13.80720 & $\odot . \odot \odot \odot \odot \odot$ & $\odot . \odot \odot \odot \odot \odot$ & $\odot .00000$ \\
\hline 17 & 19 & 18 & 20 & 3 & 9.20480 & $\odot .0 \odot \odot \odot \odot$ & -9.20480 & $\odot . \odot \odot \odot \odot \odot$ & $\odot .0 \odot \odot \odot \odot$ & $\odot .0000 \odot$ \\
\hline 4 & 1 & 5 & 2 & 3 & 87.86400 & $\odot . \odot \odot \odot \odot \odot ~$ & -87.86400 & $\odot . \odot \odot \odot \odot \odot$ & $\odot . \odot \odot \odot \odot \odot$ & $0.0000 \odot$ \\
\hline
\end{tabular}




\section{References:}

1. Dong, Y.; Pang, H.; Yang, H. B.; Guo, C.; Shao, J.; Chi, Y.; Li, C. M.; Yu, T. Carbon-Based Dots Co-Doped with Nitrogen and Sulfur for High Quantum Yield and Excitation-Independent Emission. Angew. Chem. Int. Ed. 2013, 52, 78007804.

2. Stoll, S.; Schweiger, A. Easyspin, a Comprehensive Software Package for Spectral Simulation and Analysis in EPR. J. Magn. Reson. 2006, 178, 42-55.

3. Mura, S.; Stagi, L.; Malfatti, L.; Carbonaro, C. M.; Ludmerczki, R.; Innocenzi, P. Modulating the Optical Properties of Citrazinic Acid through the Monomer-To-Dimer Transformation. J. Phys. Chem. A 2020, 124, $197-203$.

4. Schwerzel, R. E.; Caldwell, R. A. Quenching of Excited States by Stable Free Radicals. II. Mechanism of Triplet Quenching by Di-Tert-Butyl Nitroxide. J. Am. Chem. Soc. 1973, 95, 1382-1389.

5. Holá, K.; Sudolská, M.; Kalytchuk, S.; Nachtigallová, D.; Rogach, A. L.; Otyepka, M.; Zbořil, R. Graphitic Nitrogen Triggers Red Fluorescence in Carbon Dots. ACS Nano 2017, 11, 12402-12410.

6. Siddique, F.; Langer, M.; Paloncýová, M.; Medved, M.; Otyepka, M.; Nachtigallova, D.; Lischka, H.; Aquino, A. J. A. Conformational Behavior and Optical Properties of a Fluorophore Dimer as Model of Luminescent Centers in Carbon Dots. J. Phys. Chem. C 2020, 124, 14327-14337.

7. Paloncýová, M.; Langer, M.; Otyepka, M. Structural Dynamics of Carbon Dots in Water and N,NDimethylformamide Probed by All-Atom Molecular Dynamics Simulations. J. Chem. Theory Comput. 2018, 14, $2076-2083$. 8. Wang, J.; Wang, W.; Kollman, P. A.; Case, D. A. Automatic Atom Type and Bond Type Perception in Molecular Mechanical Calculations. J. Mol. Graphics Modell. 2006, 25, 247-260.

9. Cheng, A.; Steele, W. A. Computer Simulation of Ammonia on Graphite. I. Low Temperature Structure of Monolayer and Bilayer Films. J. Chem. Phys. 1990, 92, 3858-3866.

10. Caleman, C.; van Maaren, P. J.; Hong, M.; Hub, J. S.; Costa, L. T.; van der Spoel, D. Force Field Benchmark of Organic Liquids: Density, Enthalpy of Vaporization, Heat Capacities, Surface Tension, Isothermal Compressibility, Volumetric Expansion Coefficient, and Dielectric Constant. J. Chem. Theory Comput. 2012, 8, 61-74.

11. van der Spoel, D.; van Maaren, P. J.; Caleman, C. GROMACS Molecule \& Liquid Database. Bioinformatics 2012, 28, 752-753.

12. Berendsen, H. J. C.; Grigera, J. R.; Straatsma, T. P. The Missing Term in Effective Pair Potentials. J. Phys. Chem. 1987, 91, 6269-6271.

13. Aंqvist, J. Ion-Water Interaction Potentials Derived from Free Energy Perturbation Simulations. J. Phys. Chem. 1990, 94, 8021-8024.

14. Hess, B.; Bekker, H.; Berendsen, H. J. C.; Fraaije, J. G. E. M. Lincs: A Linear Constraint Solver for Molecular Simulations. J. Comput. Chem. 1997, 18, 1463-1472.

15. Bussi, G.; Donadio, D.; Parrinello, M. Canonical Sampling through Velocity Rescaling. J. Chem. Phys. 2007, 126, 014101.

16. Berendsen, H. J. C.; Postma, J. P. M.; van Gunsteren, W. F.; DiNola, A.; Haak, J. R. Molecular Dynamics with Coupling to an External Bath. J. Chem. Phys. 1984, 81, 3684-3690.

17. Darden, T.; York, D.; Pedersen, L. Particle Mesh Ewald: An N·Log(N) Method for Ewald Sums in Large Systems. J. Chem. Phys. 1993, 98, 10089-10092.

18. Van Der Spoel, D.; Lindahl, E.; Hess, B.; Groenhof, G.; Mark, A. E.; Berendsen, H. J. C. Gromacs: Fast, Flexible, and Free. J. Comput. Chem. 2005, 26, 1701-1718. 